\title{
From marine ecology to biological oceanography
}

\author{
Eric L. Mills \\ Department of Oceanography, Dalhousie University; Halifax, Nova Scotia, B3H $4 \mathrm{~J} 1$ \\ Canada
}

\begin{abstract}
Looking back from the 1990s it seems natural to view the work done in the Biologische Anstalt Helgoland by Friedrich Heincke and his colleagues, beginning in 1892, as marine ecology or marine biology, and that done in Kiel, under Victor Hensen and Karl Brandt, as biological oceanography. But historical analysis shows this view to be untenable. Biological oceanography, as a research category and a profession, does not appear until at least the 1950's. In the German tradition of marine research, "Ozeanographie", originating in 19th century physical geography, did not include the biological sciences. The categories "Meereskunde" and "Meeresforschung" covered all aspects of marine research in Germany from the 1890's to the present day. "Meeresbiologie" like that of Brandt, Heincke, and other German marine scientists, fitted comfortably into these. But in North America no such satisfactory professional or definitional structure existed before the late 1950 's. G. A. Riley, one of the first biological oceanographers, fought against descriptive, nonquantitative American ecology. In 1951 he described biological oceanography as the "ecology of marine populations", linking it with quantitative population ecology in the U.S.A. By the end of the 1960 's the U.S. National Science Foundation had recognized biological oceanography as a research area supported separately from marine biology. There was no need for the category "biological oceanography" in German marine science because its subject matter lay under the umbrella of "Meereskunde" or "Meeresforschung". But in North America, biological oceanography - a fundamental fusion of physics and chemistry with marine biology - was created to give this marine science a status higher than that of the conceptually overloaded ecological sciences. The sociologists Durkheim and Mauss claimed in 1903 that, "the classification of things reproduces the classification of men"; similarly, in science, the classification of professions reproduces the status that their practitioners hope to achieve.
\end{abstract}

"The marine biologist in particular will continue to be a powerful ally to the oceanographer; for, in any expedition he may undertake, strictly oceanographic observations are essential to his biological studies. He will, as in the past, make important contributions to oceanography, although engaged under the banner of marine biology" (H. A. Marmer, 1934, p. 34)

\section{DEFINING OCEANOGRAPHY}

Viewed from 1992, 100 years after the formation of the Biologische Anstalt Helgoland, it is easy to see Helgoland as the location of a succession of important studies in marine biology, while, only 150 kilometres to the east, in Kiel, a new scientific discipline, biological oceanography, was evolving. But this is a facile and present-centered view that is not borne out by historical analysis. If we look at late 19th century Helgoland and Kiel through the historical microscope, disciplinary boundaries blur and our late 20th century 
categories become anachronistic, even damaging, to a full understanding of how and why professions evolved in marine sciences during the late decades of the 19th century and the first three decades of our own century.

Examining the word "oceanography" gives us a clue about how not to proceed in understanding the relationship between marine biology and oceanography. Let me begin with a series of definitions or explanations of that word, chronologically ordered, with the understanding that a definition is an attempt to create a classification - that is, to make order by categorizing events or things in the world - whether that world be of the present or of the past.

In late 19th century German science, as Paffen and Kortum (1984) have shown, "Oceanographie", the study of the oceans, was a branch of physical geography. It is no accident that Otto Krümmel (whose early collaboration with Georg von Boguslawski led to the outstanding texts "Handbuch der Ozeanographie" $(1887,1907,1911)$, was Professor of Geography at the University of Kiel. And if we look at other books of the period (e.g. Jilek, 1857; Attlmayr, 1883), we find that they are largely descriptive accounts of the shape and disposition of the hydrosphere, often for applied purposes (the education of naval officers), and not accounts of oceanic dynamics. Only in Krümmel's last volume (1911) did dynamical physical oceanography, originating in Scandinavia, begin to appear. Biology was not included.

The geophysical stamp is evident also in English-language writings. W. A. Herdman, founder of the first Chair of Oceanography in the English-speaking world (in 1919) ${ }^{1}$ and its first incumbent, who knew and understood German work on the sea, wrote of "Oceanography, the Science of the Sea..." which to him included "the study of the sea in all aspects - physical chemical and biological" (Herdman, 1923, p. 1). His successor in Liverpool, James Johnstone, a zoologist and fisheries biologist (Cole, 1934) remained well within the German tradition. Johnstone was cognizant of the fact that marine biology had contributed more to ocean science by the 1920's than had physics and chemistry; nonetheless, his text "An introduction to oceanography" (1923) dealt with oceanography descriptively, as physical geography. In a later text, "A study of the oceans", he wrote of "... the physical geography of the ocean - that is, the modern science of oceanography" (Johnstone, 1926 p.v.), as outlining knowledge of the oceans from the Greeks to the 19th century explorers. But more was at stake, for in 1923 (p.xi) he had written that "... the science [of oceanography] blends into marine biology in such an intimate manner that two lines of treatment are now quite necessary: Physical Oceanography on the one hand and Hydrobiology on the other".

In a commemoration of Johnstone's career, published in 1934, the American tidal expert H. A. Marmer took a view of oceanography quite different from that of Johnstone. He viewed it as "a congeries of sciences, having different viewpoints and demanding diverse disciplines" (Marmer, 1934, p. 24), but although marine biology had been dominant in its early years, the emphasis had (deservedly) changed: "the application of mathematics has changed oceanography from a descriptive science into a mathematical physical science" (Marmer, 1934, p. 28). The day of marine biology in oceanography was over; the time had come to regard "... oceanography as a geophysical science, separate from marine biology" (Marmer, 1934, p. 33).

Marmer's sentiments were shared, but not where it mattered. Reporting in 1930 and 1931 for the U.S. National Academy of Sciences Committee on Oceanography (NASCO), 
which had been established to make recommendations on development of the marine sciences, H. B. Bigelow of Harvard took a broader view:

... in the further development of sea science the keynote must be physical, chemical and biological unity, not diversity, for everything that takes place in the sea within the realm of any one of these artificially divorced sciences impinges upon all the rest of them. In a word, until new vistas develop, we believe that our ventures in oceanography will be most profitable if we regard the sea as dynamic, not as something static, and if we focus our attention on the cycle of life and energy as a whole in the sea, instead of confining our individual outlook to one or another restricted phase, whether it be biologic, physical, chemical or geologic. This applies to every oceanographer: every one of us, if he is to draw the veil backward at all, must think and work in several disciplines. He must be either something of a Jack-ofall-trades or so closely in tune with colleagues working in other disciplines that all can pull together (Bigelow, 1930, p. 86).

Any other approach would hinder science, in Bigelow's view, by "setting us backward to the stage of simply gathering and accumulating facts in unrelated categories" (Bigelow, 1930, p. 89).

The preeminent North American oceanographer and moulder of the science was actually a European, H. U. Sverdrup, director of the Scripps Institution of Oceanography between 1936 and 1947. Sverdrup broadened the curriculum of the struggling Institution, took its research to sea (in collaboration with state and federal agencies), and worked with his colleagues Martin Johnson and Richard Fleming to publish the first modern text, "The oceans. Their physics, chemistry and general biology" (1942). Sverdrup had begun his career as a meteorologist with V. F. K. Bjerknes. Later he became interested in ocean circulation as a result of his experiences on Amundsen's "Maud" in the Arctic, 1918-1925 (Mills, 1991, pp. 261-265). He credited Henry Bigelow with convincing him of the need for unity in studying the oceans. As he wrote in introducing "The oceans": "Oceanography embraces all studies pertaining to the sea and integrates the knowledge gained in the marine sciences that deal with such subjects as ocean boundaries and bottom topography, the physics and chemistry of sea water, the types of current, and the many phases of marine biology", (Sverdrup et al., 1942, p. 1; see also Sverdrup, 1947, p. 78). This was not a viewpoint he had brought from Europe, where, as he said, "... there has been a tendency to draw a line between physical oceanography and the other marine sciences, a tendency which may be illustrated by the fact that there the term oceanography is generally limited in meaning to the physics of the sea only" (Sverdrup, 1955, p. 288).

Sverdrup was well placed to know. And his observation applies to marine science in Germany long before 1955. Near the end of his career, Karl Brandt, the dominant figure of the Kiel School from the 1880's until the First World War, summarized the marine zoological work carried out under the Kiel Commission between 1870 and 1920 (Brandt, 1921). In retrospect, much of this work qualifies as "oceanography". But the word does not apper in Brandt's treatise, nor did he consider it relevant, except to describe Krümmel's treatment of physical data from the North Sea and the Baltic. Brandt uses the general term "Meeresforschung" to describe German activities (mainly in Kiel and at Helgoland) in marine science; it served to unify a variety of activities, ranging from 
bacteriology to zoology, plus the chemical and physical sciences. Nearly 50 years later, Günther Dietrich's influential text "Allgemeine Meereskunde. Eine Einführung in die Ozeanographie" (first edition 1957) introduced "Ozeanographie" as a discipline that had evolved from a component of geography into a geophysical science, by becoming increasingly quantitative. In this and the second edition (1965), Dietrich made a concession to biology by including a chapter (written by Kurt Kalle) on cycles of material in the sea, but biology played a small part in his Meereskunde. It is not that "biologische Meereskunde" does not exist in Dietrich's world of the oceans - rather that the proper study of marine science is the medium itself; sea water and its properties. "Ozeanographie" gives way to the more inclusive "Meeresforschung" (equivalent to Meereskunde) which

... geht es um den Stoff, nämlich um das Meerwasser und alle in ihm gelösten und schwebenden Substanzen, es geht ihr ferner um den Raum, den das Meerwasser ausfüllt, um die Lebewesen, die diesen Raum bevölkern, und um die Energie, die dem Meere zur Verfügung steht (Dietrich, 1970, p.9).

Stoff, Raum, Lebewesen, Energie - the components of a comprehensive science of the sea - not Ozeanographie, but Meeresforschung or Meereskunde.

These examples of definitions of oceanography (or its seeming cognates), which are not intended to be a synoptic catalogue, show the futility of attempting to impose strict definitions - or any rigid classification - upon sciences that have been in constant development and in dispute since the $1880^{\prime} \mathrm{s}$. There are not standard definitions or classifications of such disciplines as "oceanography", "Meereskunde", "Meeresforschung", "marine biology" or "biological oceanography", nor should we impose them. Instead, each is a nest of historical problems requiring investigation.

\section{THE CLASSIFICATION OF THINGS AND THE CLASSIFICATION OF MEN}

This paper is an attempt to outline the parameters of a historical study, and it offers a model of development in the marine sciences. It is based on the fact that the well-known and widely-used late 20 th century term "biological oceanography" is virtually absent from the European marine science literature, and is very seldom used in Englishlanguage writings on the marine sciences until after the middle of the 20th century ${ }^{2}$. As my examples of the use of the word "oceanography" have shown, definitions and classifications - any static taxonomy of the marine sciences - will not do. The usages are too varied and too dependent upon context - or perhaps upon whim - to be satisfying. A causal analytical approach is needed to resolve the forces at work governing how professions in the marine sciences were established, elaborated, modified and named.

My approach is to look back 90 years to the work of the French social anthropologists Emile Durkheim and Marcel Mauss, who, in the words of David Bloor (1982, p. 267) proposed that "the classification of things reproduces the classification of men". Few sociological formulations have been more rigorously criticized than Durkheim and Mauss's hypothesis as it was first presented in 1903 (see especially Rodney Needham, in Durkheim \& Mauss, 1963) ${ }^{3}$. But as Bloor has shown, their thesis, that definitions and classifications "... express... the very societies within which they were elaborated" (Durkheim \& Mauss, 1963, p.66) becomes robust once it is joined with Mary Hesse's 
(1974) model of scientific knowledge, according to which our systematic knowledge of the world is an interconnected network of ideas and responses to nature, held stable by social conventions (coherence conditions). Knowledge, including our classification of the external world, is neither totally socially contingent nor governed unequivocally by facts from nature. Instead it arises as a complex interaction between natural reality, psychological perceptual factors, and the bounds and forms imposed by the societies in which we operate. The result is, as Bloor (1982, p. 293) has stated, that "knowledge is a channel which can convey two signals at once". Thus we can expect scientists' classifications of their professions to represent both the natural reality dealt with by those professions and the needs and aspirations of their practitioners. Examined in this light, marine biology and oceanography have a good deal to tell us about the development of science and its context.

\section{KIEL, HELGOLAND, AND THE INTERNATIONAL COUNCIL}

By 1892 the scientific direction of marine research in Kiel had passed from Victor Hensen to Karl Brandt. In 1888 Brandt and Carl Apstein began the lengthy series of cruises and plankton samples that would eventually show the ubiquity and the uniqueness of the spring bloom and call for its explanation. But the Plankton-Expedition of 1889 to the open Atlantic produced the most intriguing problems. Why, contrary to expectation, was the open ocean more plankton-rich in high northern latitudes than in the tropics? Within a few years (when he had recognized that the spatial variations of abundance observed in the open ocean had the same governing factors as seasonal variations evident near Kiel), Brandt embarked on a quest for chemical and physical controls of plankton abundances. Chemistry and the nitrogen cycle were the keys (Mills, 1989, Chs. 2-5).

Uniting the resources of his Zoological Institute at Kiel, the Kiel Commission, and the new German commission established to work within the International Council for the Exploration of the Sea (ICES) beginning in 1902, Brandt and his colleagues had worked out a coherent, chemically and physically based theory of the control of plankton abundance in the sea by 1910. And, as Brandt's summary (1921) of his work shows, a lot else was going on at Kiel, ranging from hydrography to marine botany and bacteriology. This broad range of activities - Meeresforschung - answered questions about the sea, classified marine organisms, and provided occupations for a range of investigators - from hireling chemists to students, Privatdozenten, and Professors such as Brandt himself. Were we anachronistically inclined, we could call Brandt and the Kiel School biological oceanographers. This would make perfect sense in a modern context.

A true German marine station had not existed before 1892, unless one counted Anton Dohrn's Stazione Zoologica in Naples (a German-based foundation established in 1872). Nor was Helgoland a German possession until 1890, when the German state acquired it from Great Britain in exchange for East African territories. Helgoland had many virtues, including a pristine, varied biota quite different from that of the Waddensee and the Baltic, a history of German natural history exploration, and access to the North Sea fishing banks. But before 1892 - as the first director of the Biologische Anstalt Helgoland, Friedrich Heincke, $(1896$, p. 2$)$ pointed out - Germany was the only coastal European nation lacking a proper marine station. 
With the support of the Emperor, the Kultusminister and his officials, the Akademie der Wissenschaften, the Deutsche Fischerei-Verein (Sektion für Hochseefischerei), and others, an advisory committee (including representatives of the Kiel Commission) completed a plan for a laboratory on Helgoland by the summer of 1891. It was under way and growing a year later (Kofoid, 1910, pp. 221-222; Heincke, 1893), despite some opposition (Werner, 1992). From the start, Heincke had ambitious plans for the laboratory, which, like the Marine Biological Laboratory at Woods Hole, the Plymouth Laboratory, and W.C. McIntosh's Gatty Marine Laboratory in Scotland, he considered to be a marine agricultural station (Heincke, 1896, p.4). Using pure and applied biology, the Helgoland laboratory would promote knowledge of the German North Sea fishery (Heincke, 1897, p. 579). Heincke's first, breathtakingly ambitious, list of aims ranged from research on the production of commercial fish, to providing courses for fishermen (Heincke, 1896, p. 3). Publication would be eased by establishing a special section of the Kiel Commissions "Wissenschaftliche Meeresuntersuchungen".

The long history of the Biologische Anstalt Helgoland on the island and in expanded form on Sylt and the mainland (outlined by Bückmann, 1959; Bulnheim, 1989, 1990), its work easily characterized now as marine biology, was based on Heincke's early aims of advancing knowledge of the North Sea fishery ${ }^{4}$. But in the early days, success required cooperation and collaboration with other agencies, such as the Kiel Commission, which was a competitor for resources such as money, ship-time and personnel. From its start in 1894, Heincke enlisted the support of the Deutsche Seefischerei-Verein and its President, Walther Herwig, who later became President of the Deutsche Kommission für internationale Meeresforschung, the German arm of ICES (Smed, 1990). Heincke was appointed to the Kiel Commission by the Minister of Agriculture in 1893, in an attempt to ensure that Helgoland and Kiel collaborated rather than competed. To a great extent this succeeded, partly due to collaboration, and partly due to the different orientations developed by the two institutions. When in 1901 Helgoland and Kiel divided up the German work for ICES, Heincke and a colleague were responsible for the food-fishes, Brandt for the general biology, and Krümmel for meteorology and hydrography (Brandt, 1921, p. 78). We know little of how this actually worked, but there are indications that Helgoland and Kiel did not always lie down together quietly; despite their division of labour, Brandt refers to agreement being necessary between the two to avoid "splintering" German marine research (Brandt, 1921, pp. 76-77). The Kiel Commission, after all, had begun work on the Baltic físhery and extended its work to the North Sea (Mills, 1989. Ch. 1) before the Helgoland laboratory was established. Only slowly, and after 1892, did the work of the two institutions diverge significantly, into what we might now call marine biology, fisheries biology and biological oceanography.

For the International Council itself, after its formation in 1902, the problem was not the division of labour but of bringing the scientific work together into the synthesis envisioned by its founders. They had stated that

... it was seen from the beginning that the study of the physical conditions, of the chemical nature of the ocean waters, of the currents etc., was of the greatest importance for the investigation of the problems connected with life, that on the other hand, the study of the floating organisms had a particular worth for the solution of hydrographic problems, and consequently that a sharp line should never be drawn 
between these two main divisions... (ICES, 1902, quoted by Sverdrup et al., 1942, p. 1).

But as Sverdrup knew (see quotation earlier), in Europe this was easier to say than to achieve. Despite the early exhortations of Johan Hjort and the later convening of special meetings to relate fisheries problems to physical oceanography (outlined by Sinclair et al., 1987, Ch. 2 and App. 1-4), physical oceanographers and marine biologists found it hard to ask the same questions, or even to find ways of talking the same scientific language (Sverdrup, 1951). In 1950, after decades of similar pleas, K. A. Anderson, the President of ICES, entitled his address at the annual meeting "Cooperation between biologists and hydrographers", calling for "a still closer liaison between hydrography and biology" to explain the distribution of herring. Oceanographers and biologists in Europe still found it easier in 1950 - perhaps preferable - to maintain their distinctiveness rather than to form permanent liaisons or to fuse their interests.

\section{OCEANOGRAPHY IN THE NEW WORLD}

Henry Bigelow began work on the Gulf of Maine in 1912. Taking time from his teaching duties at Harvard, he delineated changes in the plankton and nutrient content of the waters, and little by little arrived at a qualitative description of their circulation (Bigelow, 1926a, b). Getting the work done required means beyond his own: he was forced into an alliance with the U.S. Fish Commission (later the Bureau of Commercial Fisheries) for ships and equipment. The relationship was never perfect, changed with the political winds, and frequently drew Bigelow into work that he regarded as peripheral to his main interests (Brosco, 1989). Bigelow's opportunity to release his brand of marine science from its reliance on government agencies came in 1927, when the U.S. National Academy of Sciences established a Committee on Oceanography (NASCO), chaired by F. R. Lillie of the MBL in Woods Hole, to report on "the scope, economic importance and present status of oceanography, with recommendations as to how this science may more effectively be encouraged in America" (Bigelow, 1930, pp. 84-85). Bigelow, as secretary of NASCO, wrote the report, much of which was published under his name, as "Oceanography. Its scope, problems, and economic importance" in 1931. The immediate outcome of NASCO's report was the founding of the Woods Hole Oceanographic Institution in 1930, significant grants to the University of Washington and the Bermuda Biological Station, and a modest grant to the Scripps Institution of Oceanography, disappointing its director, T. W. Vaughan.

The Scripps Institution of Oceanography until 1930 was, at least in name, the only oceanographic laboratory in the United States. From its beginnings as a modest zoological station in San Diego in 1893 it had grown under the leadership of W. E. Ritter, who envisioned the development of an observatory of the sea, uniting the talents and the disciplines of physicists, chemists and biologists. Ritter's vision and ideal of a unified science of the sea (aimed at putting organisms in full context - he was a zoologist first) was achieved only in name at the Scripps Institution until the directorship of $H$. $U$. Sverdrup from 1936 to 1947 . Lack of funds, lack of suitable sea-going vessels, and lack of personnel kept Scripps as little more than the marine biological laboratories that were its neighbours along the U.S. coasts for the first four decades of its existence. 
Bigelow's report for NASCO provided a professional raison d'être that was not only sanctioned by the National Academy of Sciences but given financial support by the wealth of the Rockefeller Foundation. Oceanography was to be a 'mother science': "every oceanic biologist should... be grounded in the principles of geophysics and geochemistry; every chemical or physical oceanographer in some of the aquatic aspects of biology" (Bigelow, 1931, p.4). According to Bigelow, who had experienced the practical difficulty of trying to justify pure science to his patrons at the Bureau of Fisheries (Brosco, 1989), oceanography could only grow by the fusion and integration of previously separate disciplines. He concluded his lengthy argument about the support of one discipline by another by asserting that there was

... no need to quote more examples to show that the different disciplines of oceanography inevitably interlock, or to prove the intellectual necessity of not only recognizing but indeed acting upon this unity, if we hope ever to gain a thorough understanding of the sea and its inhabitants. Any attempts (conscious or unconscious) to hold them apart can result only in frustrating this high aim and in setting us backward to the stage of simply gathering and accumulating facts in unrelated categories (Bigelow, 1930, p. 89; 1931, p. 263).

The "oceanic biology" that was his specialty (Bigelow was a zoologist) required little further justification. Classical disciplines with solid institutional foundations, such as taxonomy and ecology, were easily incorporated into "oceanic biology". They, along with physiology and bacteriology, could be brought together to build understanding of the marine production cycle (Bigelow, 1931, pp. 130-132). This, in turn, required chemical knowledge, understanding of circulation, and perhaps even of the configuration of ocean basins, which ultimately controlled the nature of circulation and thus the nutrient supply and the distribution of organisms. "Oceanic biology" took its place with the hard sciences.

Before World War 2, only Bigelow's incipient project to study the production cycle on Georges Bank based at Woods Hole and using the new research vessel "Atlantis" was modelled on the ideals he set out in 1930. H. U. Sverdrup (as mentioned earlier), whose text "The oceans" was used by a generation of oceanographers, claimed to have been convinced by Bigelow's arguments of the unity of biology, chemistry, physics and geology in oceanography. But the war and his return to Norway slowed the impact of his ecumenical ideas. Sverdrup's influence was renewed on the U.S. west coast after the war, but in a new context. As H. N. Scheiber $(1986,1988,1990 \mathrm{~b})$ has shown, marine biology became integrated into oceanography because of very practical concerns. Among these were the expansion of U.S. interests in the Pacific, expressed in and realized as the expansion of the tuna fishery, and attempts to understand fluctuations in California's sardine populations. Out of the first came the Pacific Ocean Fishery Investigations (POFI, 1947) and the Inter-American Tropical Tuna Commission (1949), out of the second the California Cooperative Oceanic Fishery Investigations (CalCOFI) (1948 - see Scheiber, 1990a). All three integrated biological work on the Pacific with its physics and chemistry during the late $1940^{\prime}$ and 1950's. Through the agency of biologists like W. M. Chapman and $M$. B. Schaefer, broad oceanic studies and surveys, including marine biology, became a hallmark of U.S. oceanography on the west coast 
As Scheiber (1988, p. 226) has written, "in sum, the 'new oceanography' - which involved not only its conceptual transformation but also its emergence as part of Big Science in the organization and scale of sponsored research - had taken form and begun to flourish". Although he credits Sverdrup with bringing this viewpoint to American science from Europe, it seems likely to me, based on Sverdrup's own statements, that we can look to Bigelow for the conceptual foundations and the programmatic outline of marine biology's integration into oceanography in the United States after World War 2, beginning in California.

Just after the war, with the exception of the major projects in California described above, biologists found themselves in uncharted waters in relation to oceanography. According to Scheiber (1988, p. 225),

although a few prominent marine biologists had begun to examine the ecological relationships between biological phenomena and the chemical and physical aspects of ocean environments, there was no real unity of ocean studies, either conceptually or in the organization of the profession.

What seemed clear, however, to marine biologists, was that the post-war expansion of oceanography was passing them by, both financially and professionally.

This viewpoint was supported by high-level committees examining the state of oceanography in the United States in the first decade or two after the war. A new NASCO (unrelated to the first) was convened in 1949 to review the post-war status of American oceanography. The committee predicted a modest expansion of American oceanography that should be based on institutional changes in laboratories and universities and on increases of funding. "Marine biology" was a special problem.

For several years it has been difficult to obtain the necessary financial support for marine biology, as the outcome of such investigations has been uncertain. In the past, data accumulated so rapidly that much of it was only superficially examined and reported upon. This was due to the slow and crude methods both at sea and in the laboratory. New and more quantitative methods are necessary. New gear for use at sea while a vessel is under way is in the developmental stages, and new laboratory procedures to replace the older time-consuming methods of counting and identifying the various species are being tested. With the new understanding of water movements, it will be possible to formulate the problems more exactly and thus obviate much unnecessary collecting of data. In short, when funds become available, marine biology should make greater strides than have been possible in the last fifty years (NASCO/NRC, 1952, p. 11).

In 1951, more than half the financial support for oceanography came from the U.S. Department of Defense. The result, as the NASCO report concluded, was that, although some aspects of oceanography had prospered (physical oceanography, geophysics and acoustics were examples), others had not, and that "under the present system of government subsidy in oceanography some important scientific problems tend to be neglected" (NASCO/NRC, 1952, pp. 17-18). Due to the imbalance of funds directed to applied problems, including defense-related oceanography, pure science was put at a disadvantage, marine biology in particular was difficult to support unless it had some direct relevance to the fisheries. Using the terms for the first time in their report the 
NASCO members recommended that biological oceanography be given special funding, because, as they stated, it, with chemical oceanography, presented "many of the most challenging problems of the sea" (NASCO/NRC, 1952, p. 27).

A decade later the same complaint was voiced by a third NASCO, whose report was published in 1959/1962 after a decade of truly astonishing growth in oceanography ${ }^{5}$. Study of "the ways of life in the sea" ("biological oceanography" was not mentioned) was still under-funded, but the kind of marine biology described in the committees' report had begun to shift. Earlier reports had described the marine biology applied to the open oceans as a kind of conglomerate, variously composed of taxonomic work, ecological and zoogeographic studies, marine physiology and microbiology. In 1959, a new mode of doing oceanic biology appeared, under the heading of "Ocean-wide surveys" (NASCO/ NRC, 1959, 1962, Ch. 9, pp. 5-6).

The ultimate objective of a biological survey must be to obtain as clear a picture as possible of the communities of living marine organisms, population sizes, and productivity. Measurements should be made of the fertility and primary productivity in different ocean areas on a seasonal basis and specimens for taxonomic and zoogeographical studies should be collected.

The exponent of this kind of programme, already under way in Hawaii and California, was Gordon A. Riley, then a member of the Bingham Oceanographic Laboratory at Yale University, and member of the third NASCO. His career shows that more than funding was at stake in the success with which marine biology and other ocean sciences came together.

\section{G. A. RILEY AND BIOLOGICAL OCEANOGRAPHY}

Gordon Riley began his scientific career as an embryologist. As a new graduate student at Yale in 1934 he met the limnologist and ecologist G. Evelyn Hutchinson, whose personality, work and ideas persuaded Riley to leave embryology for limnology. Towards the completion of his doctoral thesis in 1937, he went to sea for the first time on Woods Hole's research vessel "Atlantis". Riley discovered that he liked working at sea, and that the quantitative approach to lake ecology he had developed with Hutchinson's encouragement could be applied to a bigger and more varied environment than lakes. During the next 10 years, interrupted by the war, Riley began the development of statistical, then analytical models of production processes in the sea (Mills, 1989, Ch. 10).

Riley's early work was not readily accepted, nor did it fit into a comfortable professional niche in American science. Riley and Hutchinson regarded themselves as young Turks, bringing quantitative reform to ecology, which in the United States appeared to have degenerated into a fruitless search for unifying principles without any philosophical basis upon which to base them (for a review of American ecology, see Kingsland, 1991). H. A. Marmer, even with his monochromatic view of oceanography, had identified the problem during the $1930^{\circ}$ s:

... the compilation of a body of knowledge represents only the preliminary stage in the development of a science. It is only when the various groups of facts in this body are correlated and interrelated through generalizations of wider range that we may 
properly speak of it as a science. This latter stage of development in oceanography has tended to limit its scope, and more especially, has shifted its focus from marine biology (Marmer, 1934, p. 28).

But there was an example to be followed from within ecology - mathematical population biology of the kind developed by Raymond Pearl and A. J. Lotka, Vito Volterra and G. F. Gause, which attempted to use rigorously mathematical techniques to describe, if not to explain, population growth and the competitive relations of organisms (Kingsland, 1991, pp. 7-10). It was in this sense, in 1952, that Riley defined biological oceanography as "the ecology of marine populations". He agreed that much of oceanography was overly descriptive but that,

there have been attempts to go further, to understand the geographical and seasonal variations of populations in terms of basic environmental factors, to follow the transfer of matter and energy through the food chain from green plants to successive trophic levels of animals and back to the reservoir of the environment, and to understand the physiological processes and feeding habits that make this transfer possible. These are some of the aims of biological oceanography (Riley, 1952, p. 80).

And these were Riley's own aims, realized in his quantitative models, and promoted in a lengthy series of publications (including, especially, Riley, 1953). For Riley, biological oceanography originated in ecology, but aithough it could not be divorced from ecology, the flaws in ecology (including non-quantitative marine biology) required reorientation from a grab-bag of semi-defined concepts to clear, stepwise analytical approaches to variation in nature. Oceanography provided the appropriate home for this kind of science, rather than ecology, because of its quantitative nature ${ }^{6}$. The order in which he listed the foundational disciplines of oceanography was not random:

Oceanography may be roughly defined as the application of certain basic disciplines

- mathematics, physics, chemistry, biology and geology - to any and all oceanic problems (Riley, 1960, p. 20).

When Riley wrote these lines, marine biologists had begun to have financial success in hitching their wagons to the harder ocean sciences, as biological oceanography. The U.S. National Science Foundation (NSF) (created in 1950 - see Lomask, 1976; England, 1983) first designated biological oceanography a "critical area" in 1960 (appointing an "Ad Hoc Committee" on the subject the same year), and by 1970 had created a special programme in biological oceanography within its Division of Environmental Sciences. Marine biology remained behind in the Division of Biological and Medical Sciences, where the two subjects previously had coexisted? ${ }^{7}$. Riley's solution addressed a problem that was more professional than financial: how to conduct a quantitative ecological science under a discredited banner. Biological oceanography provided the answer to both problems (Riley, 1960, p. 20).

\section{THE CLASSIFICATION OF SCIENCES AND THE CLASSIFICATION OF MEN}

By the late 1960 's the term "biological oceanograpny" was in common use in the United States, finding its way into general publications (e.g. U.S. Naval Hydrographic 
Office, 1967) and being defined explicitly in a way that gave identity and prestige to the kinds of science - and kinds of scientists - supported from the public purse. As a newlyconstituted third NASCO wrote:

biological oceanography ... is concerned primarily with marine organisms as part of the total oceanic system and with the ocean as a habitat for life. It seeks to understand the interactions of organisms with their environment and with each other. It seeks to understand how oceanic environments affect the distribution, behaviour, evolution, and life processes of the organisms and how the organisms modify the environment. It is particularly concerned with the flux of energy and matter through the marine biosphere (NAS/NRC, 1967, p. 52).

To marine biology and marine biologists, the sea was secondary (NASCO used the word "incidental") to its organisms $s_{i}$ to biological oceanography and to biological oceanographers the sea came first, uniting the various sciences that were needed to understand it.

As I have shown, any attempt to understand the relationship between marine biology and biological oceanography is destined to fail if it is based only upon definitions of those scientific disciplines. This is so because definitions provide only a fixed point of reference; my essay has shown that only a historical examination of the relationships of the marine sciences can explain the realities of our current classifications of professions in them. Definitions change because they reflect more than the realities of nature: they are built in response to changing needs and aspirations. It is in this sense and this context that Durkheim and Mauss's hypothesis applies not just to human ordering of the natural world but to the way professions fall into relation one to the other.

I have shown that "biological oceanography" arose and was first useful primarily in a special context, the United States of the 1950's and 1960's, where a new system of funding science was growing rapidly. Marine biologists and ecologists, who had contributed inordinately to the origins of oceanography, felt neglected, not just as scientists, but especially in the extent to which they could find money for their research. Their liaison with oceanography as biological oceanographers provided not only a satisfying increase in the breadth and depth of their work, but an increase in their ability to find research funds. Increased status, money and scientific power came with marine biology's marriage to oceanography as biological oceanography during the 1950's and early 1960's.

Funding was not the only imperative. Marine ecology, though successful, was not particularly highly regarded in the hierarchies of American science between the 1930's and 1960's. Mathematical ecology was a way out for those like Gordon Riley, who regarded the semantic excesses of American ecology with scorn. The mathematica] ecology of the oceans, to Riley, was biological oceanography.

These problems and their solutions are not apparent in Europe, notably not in Germany. In German universities like Kiel, and in marine science institutes like the Biologische Anstalt Helgoland, marine biology and the other marine sciences fitted comfortably into professional and institutional settings devoted to Meereskunde, or, stressing the human actors involved, Meeresforschung. Meereskunde (or Meeresforschung) provided an umbrella under which the marine science disciplines could cluster. Hierarchies certainly existed, but given the relatively even-handed distribution of state 
and federal funds to the marine sciences in Germany until at least the 1960 's, and their concentration on applied problems like the fisheries, competition and the sense of being at a disadvantage appear to have been at a minimum in that setting. Biological oceanography was not needed.

If in Germany Meereskunde or Meeresforschung provided an umbrella for all the marine sciences, biological oceanography in the United States was a fusion of ecological and physical sciences. Marine biologists attempted to better their positions - and certainly succeeded financially and professionally - by incorporating marine chemistry and especially physical oceanography into their reconstituted realm of study during the late 1950's and early 1960's. Biological oceanography was the result, and although the name was not new it held new significance to a group of professional marine scientists in the United States beginning in the 1960's. The name stuck for good reasons and has since spread well beyond its original bounds. Biological oceanography represented the realities of life in the ocean - but it also reflected the status, financial, professional and scientific, that marine biologists working on oceanic problems hoped to achieve.

\section{NOTES}

1. Herdman's Chair, established in 1919, was occupied by him for only one year; he was succeeded by James Johnstone (1920-1934). The first chairs of oceanography anywhere were created in Paris in 1906 by Albert the First of Monaco. They were incorporated into his Institut Oceánographique when it was formally inaugurated in 1911.

2. For example, "biological oceanography" is used in a variety of contexts by Herdman, 1920, p. 3; W. E. Allen, 1927; Harvey, 1928, p. 3; Knudsen et al., 1950, Riley, 1952, p. 79, 1960, p. 20; and only fleetingly or indirectly in NASCO/NRC, 1951 and NASCO/ NRC 1959/1962. The German hydrobiologist Ernst Hentschel used the term "biologische Ozeanographie" in a recognizably modern way in a lecture to the Officers Mess on "Meteor" in September 1926. My thanks to Prof. Hjalmar Thiel for this information and for showing me the outline of Hentschel's lecture. In 1989 I imposed the term upon all the marine research involving plankton dynamics from Victor Hensen's first work in the 1880's through the 1960's (Mills, 1989; see esp. pp. 1-6).

3. Bloor's elaboration of Durkheim and Mauss in support of an interests model of scientific knowledge has been no less contentious; see the extensive commentary following his paper:

4. Heincke's early scientific contributions have been eclipsed (at least in the Englishspeaking world) by his directorship at Helgoland. See Sinclair \& Solemdal (1988).

5. The 1952 NASCO committee predicted modest growth in the funding and personnel of oceanography. Their report, almost quaint in retrospect, could not have foreseen U.S. responses in science to the Cold War, the launching of the first Soviet "Sputnik" (1957) and American euphoria (scientific and poitical) with the success of their own space programme beginning in 1958 (Kitsos, 1988, King \& Jennings, 1988). For the status of American oceanography between the two NASCO reports, see Fleming 1957 and 1968. The scientific and political context of the third NASCO is described bv Wenk (1972, pp. 39-45) 
6. A curious transitional publication illustrating this point is the "Treatise on marine ecology and paleoecology". Volume 1 (Hedgpeth, 1957). Conceived of partly as a modernization of the biological section of "The oceans", it covered all that would later be called biological oceanography, was used by oceanographers, and contained a didactic chapter on statistics in ecology aimed at resolutely non-quantitative practitioners of marine ecology.

7. The best guide to the intricacies of U.S. government funding of the marine sciences through NSF after World War 2 will be Dr. Toby Appel's forthcoming account of the U.S. National Science Foundation's support of marine biology and related sciences. I am grateful to Dr. Appel for letting me read parts of the manuscript and for discussions of this paper. A sketch of developments at this time from the viewpoint of an oceanographer (non-biological) is Knauss (1988). Views from inside the political power structure are given by Wenk (1972), and Price (1965, pp. 209-269) shows how complex was the growth of U.S. oceanography in professional and political terms during the 1960 's.

\section{LITERATURE CITED}

Allen, W. E., 1927. Pressing needs in the field of biological oceanography. - Bull. Scripps Instn. Oceanogr. (Non-tech. Ser.) 13,1-15.

Attlmayr, F. (Ed.), 1883. Handbuch der Ozeanographie und maritimen Meteorologie. K.-K. Hof- \& Staatsdr., Wien, 1-2, 1-990.

Bigelow, H. B., 1926a. Physical oceanography of the Gulf of Maine. - Bull. Bur. Fish., Wash. 40 (2), 511-1027.

Bigelow, H. B., 1926b. Plankton of the offshore waters of the Gulf of Maine. - Bull. Bur. Fish., Wash. $40(2), 1-509$

Bigelow, H. B., 1930. A developing view-point in oceanography. - Science, N.Y. 71, 84-89.

Bigelow, H. B., 1931. Oceanography, its scope, problems, and economic importance. Houghton Mifflin, Boston, $263 \mathrm{pp}$.

Bloor, D., 1982. Durkheim \& Mauss revisited. Classification and the sociology of knowledge. - Stud. Hist. Phil. Sci. 13, 267-297.

Boguslawski, G. von \& O. Krümmel, 1887. Handbuch der Ozeanographie. II.: Die Bewegungsformen des Meeres. Engelhorn, Stuttgart, $592 \mathrm{pp}$.

Brandt, K., 1921. Die zoologischen Arbeiten der Kieler Commission 1870-1920. In: Festschrift der Preussischen Kommission zur wissenschaftlichen Untersuchungen der deutschen Meere zu Kiel. Lipsius \& Tischer, Kiel, 76-194.

Brosco, J. P., 1989. Henry Bryant Bigelow, the U.S. Bureau of Fisheries, and intensive area study. Soc. Stud. Sci, $19,239-264$.

Bückmann, A. (Ed.), 1959. Die Wiederöffnung der Biologischen Anstalt Helgoland auf der Insel Helgoland. - Helgoländer wiss. Meeresunters. 7, 1-50.

Bulnheim, H.-P, 1989. The Biologische Anstalt Helgoland - some historical events. - Dt. hydrogr $Z$ Erg. $-H$. (Reihe B), 21, $99-110$.

Bulnheim, H, P., 1990. A century of marine zoological and ecological research around Helgoland Island. Dt. hydrogr Z Erg. $\mathrm{H}$ (Reihe B) 22, 84-93.

Cole, F. J., 1934. "J.J." A biographical note. In: James Johnstone memorial volume. Ed. by R. J. Daniel Liverpool Univ. Press, Liverpool, 1-11.

Dietrich, G., 1957. Allgemeine Meereskunde, Borntraeger, Berlin, $492 \mathrm{pp}$.

Dietrich, G. (Hrsg.), 1970. Erforschung des Meeres. Umschau Verl. Frankfurt, $318 \mathrm{pp}$,

Durkheim, E. \& Mauss, M., 1963. Primitive classification. Cohen \& West, London, 96 pp.

England, J.M, 1983. A patron for pure science, the National Science Foundation's formative years, 1945-57. National Science Foundation, Washington, $443 \mathrm{pp}$. 
Fleming, R. H., 1957. Present status and future development of oceanography. - Proc. Pacif. Sci. Congr, 8 (3A), 1177-1196.

Fleming, R. H., 1968. The history of education in oceanography. Dept. of Oceanography, Univ. of Washington, Seattle, $14 \mathrm{pp}$.

Harvey, H. W., 1928. Biological chemistry and physics of seawater. Cambridge Univ. Press, Cambridge, $194 \mathrm{pp}$.

Hedgpeth, J. W. (Ed.), 1957. Treatise on marine ecology and paleoecology. Geol. Soc. Am., New York, 1, 1-1296.

Heincke, F., 1893. Die Biologische Anstalt auf Helgoland. - Bot. Zbl. 54, 139-142.

Heincke, F., 1896. Die Biologische Anstalt auf Helgoland und ihre Tätigkeit im Jahre 1893. - Wiss. Meeresunters. (Helgoland) 1, 1-33.

Heincke, F., 1897. Die Thätigkeit der Kgl. Biologischen Anstalt auf Helgoland. - Wiss. Meeresunters. (Helgoland) 2,537-579.

Herdman, W. A., 1920. Oceanography and the sea-fisheries. - Rep. Br. Ass. Advmt Sci. 88, 1-33

Herdman, W. A., 1923. Founders of oceanography and their work. Arnold, London, 340 pp.

Hesse, M. B., 1974. The structure of scientific inference. Macmillan, London, $309 \mathrm{pp}$.

Jilek, A. (Hrsg.), 1857. Lehrbuch der Oceanographie zum Gebrauche der k.k. Marine-Akademie. K.-K. Hof- \& Staatsdr., Wien, 298 pp.

Johnstone, J., 1908. Conditions of life in the sea. Cambridge Univ. Press, Cambridge, $332 \mathrm{pp}$.

Johnstone, J., 1923. An introduction to oceanography, with special reference to geography and geophysics. Hodder \& Stoughton, London, $351 \mathrm{pp}$.

Johnstone, J., 1926. A study of the oceans. Arnold, London, $215 \mathrm{pp}$.

King, L. R. \& Jennings, F. D., 1988. The executive and the oceans: three decades of United States marine policy. - J. mar. Technol. Soc. 22, 17-32.

Kingsland, S., 1991. Defining ecology as a science. In: Foundations of ecology. Ed. by L. A. Real \& J. H. Brown. Univ. of Chicago Press, Chicago, 1-13.

Kitsos, T. A., 1988. Congress and the oceans: shaping marine policy for three decades. - J. Mar. Technol. Soc. 22, 33-49.

Knauss, J., 1988. Academic oceanography: how we got from there to here. - J. Mar. Technol. Soc. 22, 5-11.

Knudsen, V. O., Redfield, A. C., Revelle, R. \& Shrock R. R., 1950. Education and training of oceanographers. - Science, N.Y. 111, 700-703.

Kofoid, C. A., 1910. The biological stations of Europe. U.S. Bureau of Education, Washington, 360 pp.

Krümmel, O., 1907. Handbuch der Ozeanographie. Bd. I: Die räumlichen, chemischen und physikalischen Verhältnisse des Meeres. Engelhorn, Stuttgart, 526 pp.

Krümmel, O., 1911. Handbuch der Ozeanographie. Bd. II: Die Bewegungsformen des Meeres. Engelhorn, Stuttgart, $766 \mathrm{pp}$

Lomask, M., 1976. A minor miracle - an informal history of the National Science Foundation. National Science Foundation, Washington, $285 \mathrm{pp}$.

Marmer, H. A., 1934. The scope of oceanography. In: James Johnstone memorial volume. Ed. by R. J. Daniel. Liverpool Univ. Press, Liverpool, 22-34.

Mills, E. L., 1989. Biological oceanography. Cornell Univ. Press, Ithaca, 378 pp.

Mills, E. L., 1991. The oceanography of the Pacific: George F. McEwen, H.U. Sverdrup and the origin of physical oceanography on the west coast of North America. - Ann. Sci. 48, 241-266.

NASCO (National Academy of Sciences - National Research Council), 1952. Oceanography 1951 National Acad, of Sciences, Washington, $36 \mathrm{pp}$.

NASCO (National Academy of Sciences - National Research Council), 1959-1962. Oceanography 1960 to 1970. National Acad. of Sciences, Washington, $240 \mathrm{pp}$.

NASCO (National Academy of Sciences-National Research Council), 1967. Oceanography 1966. Achievements and opportunities. National Acad. of Sciences, Washington, $183 \mathrm{pp}$.

Paffen, K.-H. \& Kortum, G., 1984. Die Geographie des Meeres.- Kieler Geogr. Schr. 60,1-293.

Price, D. K. 1965. The scientific estate. Harvard Univ. Press, Cambridge, 323 pp.

Riley, G. A. 1952. Biological oceanography. In: Survey of bioloqical proqress. Ed. by G. S. Avery. Acad. Press, New York, 2, 79-104.

Riley, G. A, 1953. Theory of growth and competition in natural populations. - J. Fish. Res. Bd Can. 10, $211-233$. 
Riley, G. A., 1960. Education and manpower problems in oceanography. In: Papers: 8th Conference on Scientific Manpower. National Science Foundation, Washington, 20-24 (Publ. NSF 60-34).

Scheiber, H. N., 1986. Pacific ocean resources, science and the law of the sea: Wilbert M. Chapman and the Pacific Fisheries, 1945-1970. - Ecol. Law Q. 13, 381-534.

Scheiber, H. N., 1988. Wilbert Chapman and the revolution in U.S. Pacific Ocean science and policy, 1945-1951. In: Nature in its greatest extent. Ed. by R. MacLeod \& P. F. Rehbock. Univ. of Hawaii Press, Honolulu, 223-244.

Scheiber, H. N., 1990a. California marine research and the founding of modern fisheries oceanography: CalCOFI's early years, 1947-1964. - Calif. coop. oceanic Fish. Invest. Rep. 31, 63-83.

Scheiber, H. N., 1990b. Pacific fishery studies, 1945-1970, oceanography, geopolitics, and marine fisheries expansion. - Dt. hydrogr. Z. Erg.-H. (Reihe B) 22, 417-421.

Sinclair, M., Loder, J. W., Gascon, D., Horne, E. P., Perry, I. \& Sandeman, E. J., 1987. Fisheries needs for physical oceanographic information within the Atlantic zone. - Can. tech. Rep. Fish. aquat. Sci. 1568, 1-166.

Sinclair, M. \& Solemdal, P., 1988. The development of "population thinking" in fisheries biology between 1878 and 1930. - Aquat. living Resour. 1, 189-213.

Smed, J., 1990. Walther Herwig: the first president of the International Council for the Exploration of the Sea (ICES). - Dt. hydrogr. Z. Erg.-H. (Reihe B) 22, 323-329.

Sverdrup, H. U., 1947. New international aspects of oceanography. - Proc. Am. phil. Soc. 91, 75-78.

Sverdrup, H. U., 1951. Some remarks on the place of hydrography in fisheries research. - Rapp. P.-v. Réun. Cons. perm. int. Explor. Mer. 131,7.

Sverdrup, H. U., 1955. The place of physical oceanography in oceanographic research. $-J$. mar. Res. $14,287-294$.

Sverdrup, H.U., Johnson, MW. \& Fleming, R. H., 1942. The oceans. Prentice-Hall, Englewood Cliffs, $1087 \mathrm{pp}$.

U.S. Naval Oceanographic Office, 1967. Science and the sea. U.S. Government Print. Office, Washington, $80 \mathrm{pp}$.

Wenk, E., 1972. The politics of the ocean. Univ. of Washington Press, Seattle, 590 pp.

Werner, P., 1992. Anton Dohrn und die Gründung der Biologischen Anstalt Helgoland. In: Historisch-meereskundliches Jahrbuch. Ed. by W. Lenz \& B. Watermann. Reimer, Berlin 1, 45-54. 